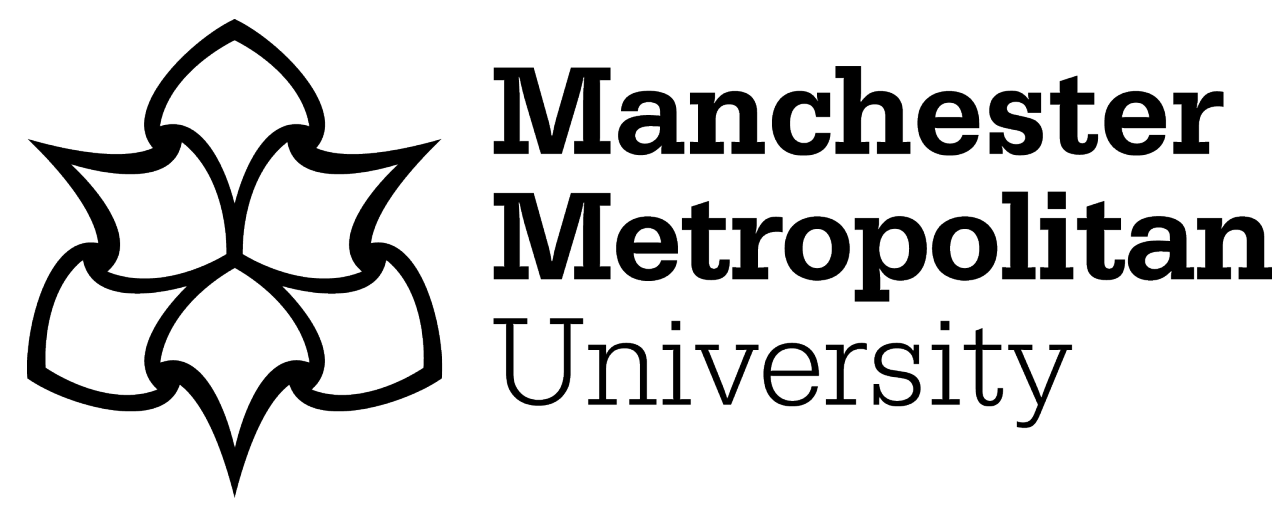

Martins, VWB, Rampasso, IS, Anholon, R, Quelhas, OLG and Leal Filho, W (2019) Knowledge management in the context of sustainability: Literature review and opportunities for future research. Journal of Cleaner Production, 229. pp. 489-500. ISSN 0959-6526

Downloaded from: https://e-space.mmu.ac.uk/623043/

Version: Accepted Version

Publisher: Elsevier

DOI: https://doi.org/10.1016/j.jclepro.2019.04.354

Usage rights: Creative Commons: Attribution-Noncommercial-No Derivative Works 4.0

Please cite the published version 


\title{
Knowledge management in the context of sustainability: literature review and opportunities for future research
}

Journal of Cleaner Production Volume 229, 20 August 2019, Pages 489-500

https://www.sciencedirect.com/science/article/pii/S0959652619314519

\author{
Martins, V.W.B ${ }^{\mathrm{a}, \mathrm{b}}$; Rampasso, I.S ${ }^{\mathrm{a}}$; Anholon, R ${ }^{\mathrm{a}}$; Quelhas, O.L.G ${ }^{\mathrm{c}}$; Leal Filho, $\mathrm{W}^{\mathrm{d}}$ \\ ${ }^{a}$ School of Mechanical Engineering, University of Campinas. Mendeleyev Street, 200. Campinas, \\ SP, Brazil. \\ ${ }^{\mathrm{b}}$ Department of Production Engineering, State University of Pará, Travessa Dr. Enéas Pinheriro, \\ 2626. Belém, PA, Brazil. \\ ${ }^{\mathrm{c}}$ Laboratory of Technology, Business and Environment Management. Federal Fluminense \\ University. Passo da Pátria Street, 156. Niterói, RJ, Brazil. \\ ${ }^{d}$ Hamburg University of Applied Sciences. Faculty of Life Sciences Lohbruegger Kirchstraße \\ 65, Sector S4, Hamburg, Germany. (*corresponding author)
}

Emails: vitor.martins@uepa.br (Martins, V.W.B.); izarampasso@gmail.com (Rampasso, I.S.); rosley@fem.unicamp.br (Anholon, R.); osvaldoquelhas@id.uff.br (Quelhas, O.L.G.); walter.leal2@haw-hamburg.de (Leal Filho,W.)

\begin{abstract}
The use of knowledge management in the context of sustainability has been increasingly important over the years. Despite this importance, it is observed that this area is still little explored and there are many possibilities of academic research. Following a structured research protocol, the authors of this article performed a systematic review of the literature and identified plausible gaps to be explored in the development of future research. These gaps are presented in relation to the themes, strategies, objectives and research approach. From the point of view of the themes, there are opportunities related to the study of sustainability in small and medium enterprises, in relation to the potential of universities as engines for the generation of knowledge and in concerning the insertion of knowledge management to propose guidelines for obtaining productive systems. Regarding research strategies, the lack of studies that use action research as central focus
\end{abstract}


stands out. Focusing on the objectives, there are many research approaches used with the goal of developing models and specific tools directed to the sharing of information. Finally, regarding the approach, there are few studies with a quantitative approach. We believe that the information presented here can contribute to the evolution of knowledge management focused on sustainability. No similar studies were found in the literature.

\section{Highlights}

- The deployment of knowledge management in sustainability contexts has increased over recent years

- There are gaps which need to be better understood, in terms of themes, strategies, objectives and research approach

- Research which leads to the development of models and specific tools directed to information sharing is growing

Key-words: Knowledge management; Sustainability; Sustainable Development.

\section{Introduction}

The Agenda 2030 of the United Nations as a whole and the 17 Sustainable Development Goals in particular, have provided a new momentum towards furthering the cause of sustainable development (Leal Filho, Manolas, Pace 2015) which, for the purposes of this paper, is a process leading to a more rational use of natural resources, in line with the principles of eco-efficiency, equity and social justice.

Along with its expansion in various sectors of society, sustainability has also been gaining increasing importance for organizations aimed at achieving competitive advantage (Gusmão Caiado et al., 2018; Kivilä et al., 2017; Rosati and Faria, 2019). In this context, Knowledge Management (KM) may play a relevant role (Chang et al., 2018; Reijsen et al., 2015). The reason for it is the fact that KM has been consolidating as an essential resource to ensure and consolidate competitive advantages for companies. The incentive for the search, absorption and sharing of knowledge has contributed considerably to the achievement of organizational goals. KM is considered a key strategic resource for organizations of all sizes. It is worth mentioning that because it is intangible, knowledge is characterized as complex to understand, to share and to root among the sectors of the organization. Using knowledge effectively and consistently is an important way to gain competitive advantage. Investing in $\mathrm{KM}$ is ensuring the use of all the knowledge available in an organization (Bolisani and Bratianu, 2017; Holsapple and Joshi, 2000; Huang et al., 2009; Nonaka et al., 2000; Quast, 2012; Rabeea et al., 2019; Wu and Wang, 2006).

Among the applications of $\mathrm{KM}$, it is pointed out in the literature its role in the optimization of approaches related to sustainability, as a way to manage this complex concept (Bucci and El-Diraby, 2018; Sánchez and Mitchell, 2017). In this sense, the maturation of the use of $\mathrm{KM}$ as a strategy allows the recognition of the necessary 
competencies to become an innovative organization of thought and learning, with the capacity to put the principles of sustainability into practice, needing to develop appropriate measures that reflect the objectives of sustainability (Robinson et al., 2006).

The KM used in the context of sustainability results in a change in the position of the organization, where the concern with social and environmental responsibility assumes equality of importance with the economic viability. KM may be used as the basis for sustainable development practices. Such a union is important because of the complexity of complying with the sustainability guidelines. Therefore, organizations need to increasingly rely on their knowledge-generating resources. In the context of sustainability, KM is treated as a new paradigm of development that aims to enhance compliance with the guidelines of economic, environmental and social sustainability (Chang et al., 2018; Faber and Engelen, 2005; Reijsen et al., 2015; Yigitcanlar, 2011).

According to the company's new demands, regarding the requirements to comply with the sustainability guidelines, any sustainable initiative becomes of great relevance, as it can cause lasting changes in the community involved and include several stakeholders with varied expectations (Kivilä et al., 2017). Analyzing the society's demand regarding the adoption of innovative approaches related to the current challenges of sustainability, there is a considerable need for further studies that discuss this context (Aarseth et al., 2017, 2011; Javernick-Will and Scott, 2010; Kivilä et al., 2017; Kudratova et al., 2018; Spangler et al., 2014). Due to the complexity of the sustainability concept, KM should be properly managed in order to contribute to the enhancement of the concept (Bucci and El-Diraby, 2018; Spangler et al., 2014). Therefore, the objective of this article is to perform a literature review on this subject and to point out the main research gaps in this area, in order to contribute to the development of future research on the subject. No similar studies were found in the literature.

In addition to this introductory section, this article is structured in four more sections. Section 2 presents a conceptual review of knowledge management and sustainability. Section 3 addresses the methodological aspects used in the elaboration of this systematic review of the literature. Section 4 presents the results achieved, emphasizing the central information of the articles and the main research opportunities in the area. Finally, section 5 refers to the conclusions. Finally, we present the references that were used for this research.

\section{Theoretical Background}

This section presents a conceptual review on knowledge management and sustainability, presenting the importance and relationship between the two themes. 


\subsection{Knowledge management}

Knowledge is recognized as a core competency, a primary source of competitive advantage and value creation for organizations around the world (Liu et al., 2018). In the literature, there are many authors that point out the role played by KM as an increasingly important capability for an organization to be successful, in both public and private sectors (Al Ahbabi et al., 2018; Gaviria-Marin et al., 2019; Gonzaga de Albuquerque et al., 2018). Despite the importance of KM, there are many companies presenting with difficulties to properly implement it due to the cultural barriers within organizations (Intezari et al., 2017; Liu et al., 2018; Martinsons et al., 2017). Among these problems, territoriality is highlighted by Singh (2019) as a barrier resulted from the intangibility character of knowledge. This territoriality leads people to hide information that should be shared with their coworkers. This is especially problematic when the advantages of KM are considered.

Since its introduction in the 1990s, the concept of KM has become an important area of research in modern management and leadership for academics and practitioners. There is a consensus among researchers that KM can be seen as a collaborative and integrated approach that facilitates an organization to create, capture, organize, access and use the intellectual asset for long-term sustainability and strategic advantage (Al Saifi, 2015; Hussinki et al., 2017; Peng et al., 2007; Prusak, 2014).

The importance of the consolidation of KM at the international level reflects the convergence in the practice of the use of KM in organizations. The KM practices are explained by the set of three mechanisms, namely: "learning and knowledge creation culture; organizational knowledge architecture for adaptive and exaptive capacity; and 'business model' for knowledge capitalisation and value capture” (Loon, 2019, p. 433).

The KM increases the information exchange among stakeholders, boosting the generation of innovations. Therefore, KM enables cooperation within companies (Hamdoun et al., 2018; Santoro et al., 2018; Singh and El-Kassar, 2019). Additionally, managing the information flows in the organization generates changes in KM that are beneficial to organizations. Through KM, companies are able to share information from different sectors and different groups of employees in order to obtain strategic gains (Nisar et al., 2019). Among the definitions of KM presented in the literature, it is worth highlighting the definition that considers the importance of $\mathrm{KM}$ for the creation, sharing and promotion of information both internally and externally to organizations. In this sense, KM should focus on the long term (Evangelista and Durst, 2015; Oliva et al., 2019).

The KM concept used in this research corresponds to the KM interaction in the context of sustainability. Within this concept, the exchange of information on a global scale is important for the viability of sustainable development. In this sense, KM can play an important role, due to its ability to provide the sharing of information from different periods and places (Mohamed et al., 2009). Given the increasing demand for sustainability aspects, there is a growing need for ways to improve KM processes and practices during the assessment of environmental, social and or economic impacts (Bucci and El-Diraby, 2018). This KM contribution to the different aspects of sustainability is the focus of this research and is best detailed in the following topic. 


\subsection{Sustainability}

Given the wide range of issues inherent to the concept of sustainability, the increasing volume of information related to this subject and their complexity, the insertion of KM can provide many benefits to this area of research (Chang et al., 2018; Faber and Engelen, 2005; Halati and He, 2018; Reijsen et al., 2015; Singh and El-Kassar, 2019; Yigitcanlar, 2011) and therefore needs to be further deepened.

Currently, the use of the concept of sustainability is discussed and used in several types of research around the world, which led to the dissemination of several conceptual interpretations according to the purpose of each research, resulting in the considerable extension of its meaning and importance. A widely adopted definition of sustainability is that developed in the World Commission on Environment and Development - WCEED (Brundtland, 1987, p. 41): "Sustainable development is development that meets the needs of the present without compromising the ability of future generations to meet their own needs".

In this context, it worth highlighting that concepts such as cleaner production, social responsibility, and eco-innovation contribute to meet sustainability guidelines, in which issues related to environmental awareness and the sustainable consumption of natural resources and human capital enhance the achievement of a more sustainable future (Maruyama et al., 2019; Severo et al., 2018). Moreover, cultural aspects must also be considered, since they play an important role for companies to achieve the transdisciplinary concept of sustainability (Moraes et al., 2018; Roscoe et al., 2019; Singh and Singh, 2018).

As a consequence of transdisciplinarity intrinsic to the concept of sustainability, standard definitions of sustainability can hardly encompass the dimensions of sustainability. In this sense, Biswas et al. (2018) and Bhandari et al. (2018) highlight the importance of the Triple Bottom Line (TBL) for an adequate understanding of the dimensions of sustainability. Initially created by John Elkington, the TBL ("people, profit and planet") played an important role in the search for an understanding of sustainability. According to this concept, the dimensions of sustainability are economic, social and environmental. That is, for a company to be considered sustainable, in addition to being profitable, it needs to take into account in its decision-making the social and environmental impacts of its actions (Biswas et al., 2018; Depken and Zeman, 2018; Zhang et al., 2018).

The exemplification of these dimensions becomes clearer when considering the business sector. From the point of view of the social dimension of sustainability, organizations need to be concerned with the diverse stakeholders of their operations, ranging from employees and customers to the communities around their facilities. That is, to be socially sustainable, companies must assume the responsibility for the welfare of these stakeholders (Burki et al., 2018; Kaur and Sharma, 2018). Environmental sustainability, in turn, refers to the impact that companies generate on the environment from their activities. Such impacts can be positive (reducing environmental damage) or negative (generating or aggravating environmental damage). Finally, economic 
sustainability refers to financial aspects; that is, it refers to the organization's ability to be profitable (Burki et al., 2018; Halati and He, 2018).

\section{Methodological procedures}

To conduct a literature review that identifies research opportunities regarding KM in the context of sustainability, a systematic review of the literature was carried out following a protocol to ensure the replication of this method in future researches. For this, the methodological procedure of Xavier et al. (2017) and Denyer and Tranfield (2009) was used. In it, the following steps should be taken: Formulation of the research question; Studies location; Selection and evaluation of studies; Analysis and synthesis; Reporting and use of research results. An explanation regarding each step is presented in Figure 1.

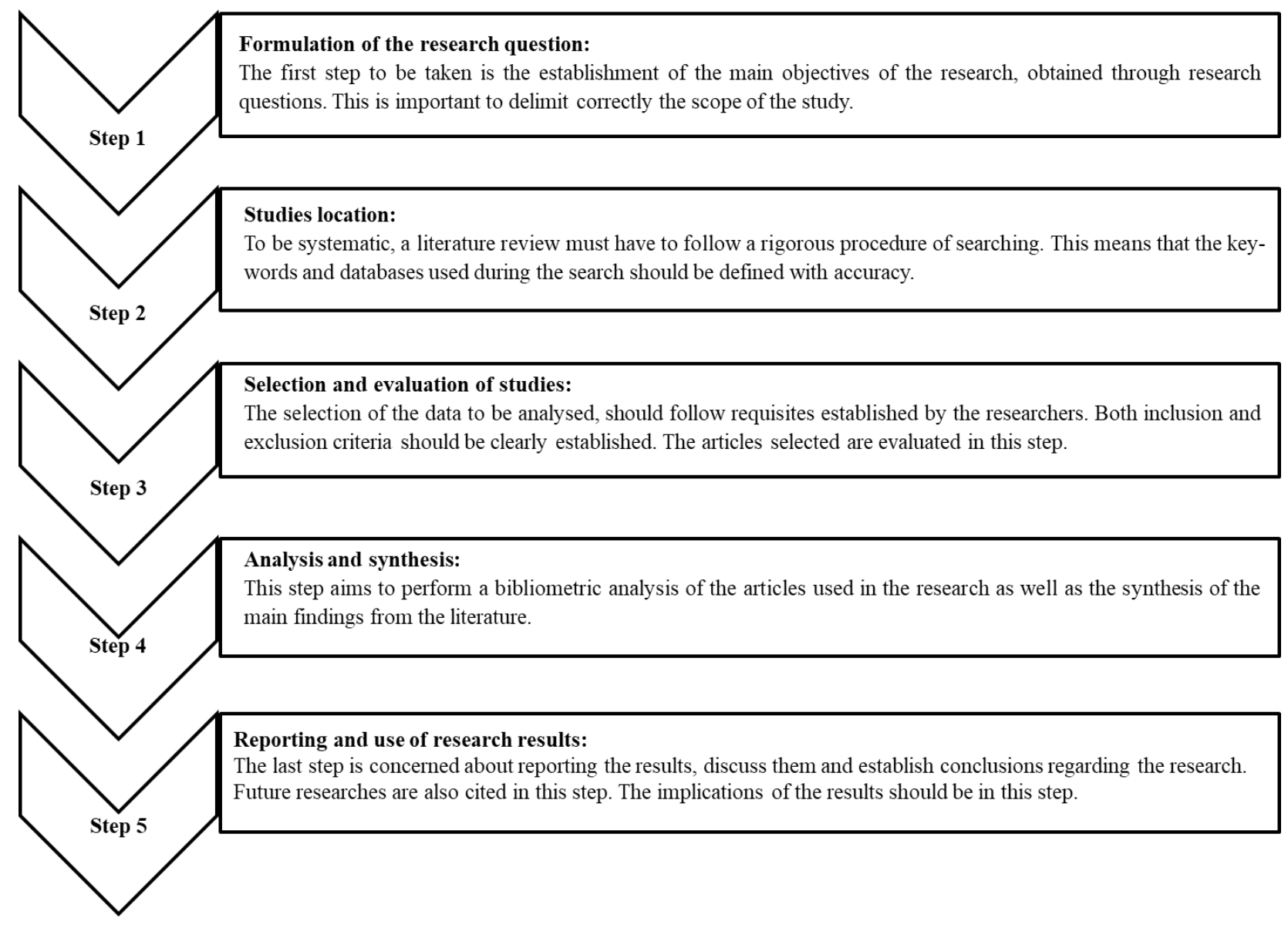

Figure 1 - Flowchart of the methodological procedure used. Source: Authors, adapted from (Denyer and Tranfield, 2009; Xavier et al., 2017). 
The results for the steps presented in Figure 1 are shown in the next section. As it is mentioned in Step 4, besides the bibliometric analysis, the core information and the methodological procedures of the analyzed articles are presented in Table 2. A discussion is performed regarding the main findings and research opportunities are pointed out in Step 5.

Following the methodological procedure of Xavier et al. (2017) and Denyer and Tranfield (2009), this study was initiated with the establishment of the research questions: Q1) What are the research opportunities regarding KM in the context of sustainability?

The next step was the definition of the location of the study, in this case, the keywords used in the search and the databases consulted. The key-words were: "Knowledge Management"; "sustainability"; "project sustainable"; "sustainable development". Different combinations of these terms were searched. The databases consulted were: Science Direct, Emerald Insight, Springer, Wiley, Taylor \& Francis and Scopus. Regarding the selection and evolution of the study, only articles from international databases were considered for the analysis. The first search resulted in 10,855 documents. The first exclusion round was made to eliminated chapters and articles from congresses. The second round was done to eliminate the documents that did not focus on their results in the subject searched here. Articles present in more that one database were considered just once. After the exclusions, 45 articles were left to be analyzed. Among these articles, there are literature reviews, study cases, surveys, and development of tools and models. However, none of them had an objective similar to ours. Regarding the analysis and synthesis step, the articles found were from a diverse number of journals. A total of 31 journals were present, and the journals: Journal of Cleaner Production and Sustainability presented the largest number of articles ( 7 and 8 articles, respectively). In Table 1, the total number of articles selected from each database is presented.

Table 1. Number of articles per database. Source: Authors

\begin{tabular}{cc}
\hline Database & Selected \\
\hline Emerald & 7 \\
Springer & 3 \\
Taylor & 3 \\
Wiley & 2 \\
Science Direct & 14 \\
Scopus & 16 \\
Total & 45 \\
\hline
\end{tabular}

In Figure 2 the publication year of the articles are shown. It is possible to verify that the theme has been increasing its number of publications since 2013. Additionally, it is worth highlighting that no restrictions were established regarding the publication period, therefore, 2004 was the first year that presented a publication regarding the scope of this research using our methodological procedures. 
Figure 2 - Chronological distribution of articles considered in the final result

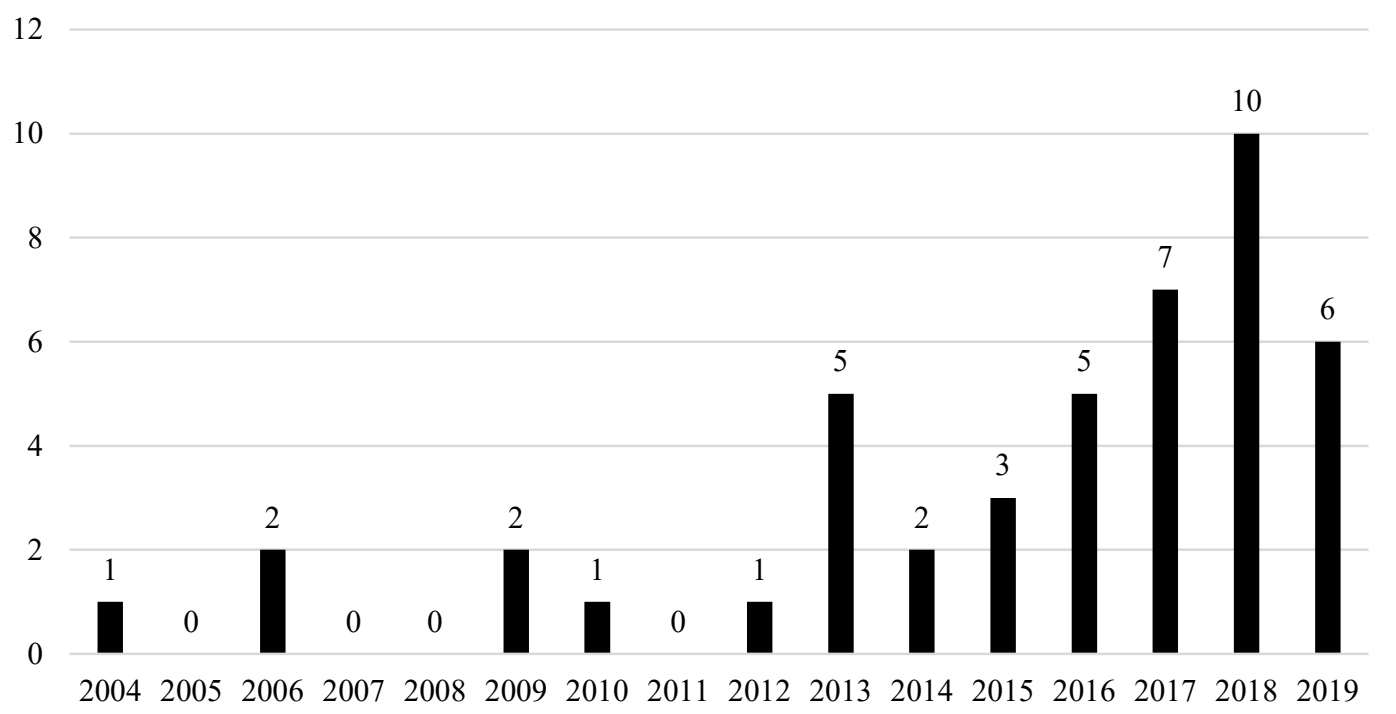

Source: Authors.

\section{Results}

From the selected articles, it was possible to create Table 2. In this table, besides information such as titles of articles, authors and journals, the central focus of each article is presented, through the analysis of the objectives and main results achieved. In addition, the methodological procedure used in each article is identified.

Table 2. Results overview. Source: Authors

\begin{tabular}{|c|c|c|c|c|c|}
\hline $\mathbf{N}^{0}$ & Article title & Reference & Journal & Core information & $\begin{array}{l}\text { Methodological } \\
\text { procedures }\end{array}$ \\
\hline 1 & $\begin{array}{l}\text { Greywater reuse: knowledge } \\
\text { management for } \\
\text { sustainability }\end{array}$ & $\begin{array}{l}\text { (Al-Jayyousi, } \\
\text { 2004) }\end{array}$ & Desalination & $\begin{array}{l}\text { It aimed to highlight the value of KM in } \\
\text { greywater reuse. It was found that knowledge } \\
\text { about water reuse is created through the } \\
\text { development of a transformation process of } \\
\text { tacit knowledge into explicit knowledge } \\
\text { through a process of socialization. }\end{array}$ & Case study. \\
\hline 2 & $\begin{array}{l}\text { Application of knowledge } \\
\text { management to environmental } \\
\text { management projects: A case } \\
\text { study for lake management }\end{array}$ & $\begin{array}{l}\text { (Sekino and } \\
\text { Nakamura, } \\
\text { 2006) }\end{array}$ & $\begin{array}{l}\text { Lakes \& Reservoirs: } \\
\text { Research and } \\
\text { Management }\end{array}$ & $\begin{array}{l}\text { It developed a KM system in order to manage } \\
\text { the information flow and storage regarding an } \\
\text { international project about lake management. } \\
\text { The developed system presented a } \\
\text { satisfactorily performance to enable users to } \\
\text { easily fetching unknown information. }\end{array}$ & Case study. \\
\hline 3 & $\begin{array}{l}\text { STEPS: a knowledge } \\
\text { management maturity } \\
\text { roadmap for corporate } \\
\text { sustainability }\end{array}$ & $\begin{array}{c}\text { (Robinson et al., } \\
\text { 2006) }\end{array}$ & $\begin{array}{c}\text { Business Process } \\
\text { Management Journal }\end{array}$ & $\begin{array}{l}\text { It showed the role of KM in the promotion of } \\
\text { corporate sustainability in the context of the } \\
\text { construction industry. The authors provided a } \\
\text { roadmap that aims to make the } \\
\text { implementation of a KM strategy easier. The } \\
\text { authors found that KM is intrinsically linked } \\
\text { to corporate sustainability. }\end{array}$ & $\begin{array}{l}\text { Survey and Multiple } \\
\text { Case Studies }\end{array}$ \\
\hline
\end{tabular}



An empirical assessment of knowledge management criticality for sustainable development

\author{
A knowledge management \\ perspective of corporate \\ social responsibility
}

Sustainable knowledge for sustainable development:

Governance for sustainability: 7 knowledge integration and multi-actor dimensions in risk management

Converting knowledge into 8 sustainability performance of freight villages

(Wu and Haasis 2013)

(Shiroyama et al., 2012)

Sustainability science: bridging the gap between science and society

Logistics Research

(Ciumasu, 2013)

Technological Forecasting \& Social Change ecilience into future eco-cities

Technology transfer of hand pumps in rural communities of Swaziland: Towards sustainable project life cycle management

The impact of sustainable construction and knowledge management on sustainability goals. A review of the Venezuelan renewable energy sector

Sustainability-Focused 12 Knowledge Management in a Global Enterprise
(Baraki and Brent, 2013)

(Pietrosemoli and Rodríguez Monroy, 2013)

(Spangler et al., Journal of Computer 2014) Information Systems

\section{Renewable and Sustainable Energy \\ Reviews}

It aimed to empirically evaluate the relevance of KM for sustainable development. A proposal for an iterative knowledge supply network was developed. The proposal describes the knowledge life cycle and supports the reduction the negative impacts of technology on sustainable development.

The authors aimed to determine the manner that $\mathrm{KM}$ processes can promote (or cease) the path of an organization towards corporate social responsibility. A conceptual model is developed of how KM can impact corporate social responsibility.

It aimed to show the challenges in achieving sustainable development in African countries without a good technological and knowledge base. The results showed through indicators of knowledge and sustainability how the knowledge capacities are highly correlated with the sustainability levels.

It proposed "an analytical framework of riskrelated governance for sustainability" (p. 45) focusing on two dimensions: knowledge integration and multi-actor governance. The results of the framework point out that these dimensions have an important role for institutions of governance that aim at sustainability.

It aimed to highlight sustainability as a strategic objective of freight villages. It proposed a roadmap to organize KM for sustainability oriented freight villages, considering the distinct characteristics of the $\mathrm{KM}$ context in freight villages.

The authors target was to integrate recent intellectual and experimental advances. The authors improves a method to be used by local communities as a tool to manage and learn urban risk issues. The results showed that the method works as a versatile learning management tool.

It aimed to understand what reasons were causing failures in hand pump. The

echnology transfer perspective was used and the research aimed to provide a greater sustainability for these hand pumps. The results indicated that important stakeholders do not use proper knowledge sharing practices.

The objective was to show the relationship between KM, sustainability and construction. In the research, KM process are faced as a mean for institutions to learn with experience of former projects and use it to improve the management of future projects related with renewable energy.

It explored opportunities related to the development of environmental management systems, in order to understand a manner to use technology within these systems to improve the sustainability results of decisionmaking. The proposed framework offers professionals a way to increase the efficiency
Survey and general linear methods.

Literature review.

Case study.

Literature review and applications of the structure in real cases.

Literature review and interviews.

Case study.

Case study.

Literature review and empirical evidence.

Case study. 
University partnerships for co-designing and coproducing urban sustainability
(Trencher et al., 2014)

Global

Environmental Change
Knowledge management in environmental sustainability practices of third-party logistics service providers

(Evangelista and Durst, 2015)

VINE
Knowledge Management Research \& Practice

Chadee, 2016) sustainability in manufacturing SMEs in the Philippines

Knowledge management in sustainability research projects: Concepts, effective models, and examples in a multi-stakeholder environment

Knowledge co-production in practice: Enabling

17 environmental management systems for ports through participatory research in the Dutch Wadden Sea

Cultivating Ecological Knowledge for Corporate Sustainability: Barilla's Innovative Approach to Sustainable Farming

Creating sustainable cities 19 through knowledge exchange: A case study of knowledge transfer partnerships

of resources uses and take decisions based in sustainability goals.

Trencher et al. (2014) developed a survey to understand the partnerships established by

Applied

(Kaiser et al., 2016)

(Puente-

Rodríguez et al. 2016)

Environmental Science \& Policy Education \& Communication

The authors focused on research projects for sustainability and the role of KM on them. In their results, they highlight the importance of sharing knowledge to boost the creation, transmission and operationalization of it.

It aimed to study the development of environmental management systems in ports through knowledge co-production. The authors found out that knowledge coproduction is increasing important in the context of port communities, especially when it is considered the different stakeholders that may contribute to preservation of these environments.

The authors examined how the collaboration between a Italian food producer, the farmers and small producers that supply the company and the scientists generated sustainability practices in the agrifood industry through the creation of ecological, technical and scientific transformative knowledge. A sustainable

(Pogutz and Business Strategy

Winn, 2016) and the Environment

farming study was performed, with indicators to analyze improvements. One of the most important result from it was the "widely accessible guidelines for sustainabilityoriented cropping knowledge and practices"

$$
\text { (p. 435). }
$$

It aimed to examine the partnership between universities and stakeholders from society to use knowledge transfer in order to boost sustainability within the cities and

International Journal (Hope, 2016) of Sustainability in Higher Education communities. The results show that the knowledge transfer partnership can be universities to seek urban sustainability. In their findings, the authors highlight the role of universities as institutions that generate knowledge.

The objective in this research was to perform a literature review regarding $\mathrm{KM}$ and $\mathrm{KM}$ for environmental sustainability in logistics companies. Three main elements properly manage the KM were identified: customer relationship management, well-trained staff and an adequate system for information and communication technology (ICT). These elements allowed the structuring of a knowledge management strategy for logistic services companies.

Roxas and Chadee (2016) aimed to present the importance of KM for small and medium enterprises to engage in environmentally sustainable businesses. The authors verified that KM was essential to insert concepts of sustainability within the companies.

Survey and Case study.

Literature review.

Survey and Partial Least Squares Structural Equation Modeling (PLSSEM).

Survey and document analyses.

Case study.

Case study. effective in the exchange of knowledge among these stakeholders, resulting in the generation of knowledge for sustainable development.
Case study. 

process
(Sánchez and Mitchell, 2017)
Environmental Review Impact Assessmen
An analysis of the interplay between organizational sustainability, knowledge management, and open innovation

\section{(Lopes et al., 2017) \\ Journal of Cleaner \\ Production}

They conducted a literature review about the KM for impact assessment for different kind of stakeholders related to sustainability projects development. The authors highlight the importance to consider learning as a result of impact assessment that may be achieved through learning organization approach. This approach is generic and can be used by many companies.

They analyzed the interface among open innovation, $\mathrm{KM}$ and sustainability, through a case study. In their analysis, the target of the company was to increase organizational sustainability via open innovation and KM.

The results of the case study carried out explored the adoption of sustainability in company's strategy through KM to promote sustainable innovations, acting as an engine to promote changes in the culture of the company. The authors provided a model that summarizes and shows the path taken by the case study to achieve eco-innovation. In this article, the organizational sustainability includes the three dimensions of sustainability that must be considered in companies' activities and products.

Knowledge management in sustainable supply chain management: Improving performance through an interpretive structural modelling approach

Sustainability focused 23 decision-making in building renovation

Mapping the knowledge flow sustainable construction project teams using social network analysis

Does intellectual capital promote the shift of healthcare organizations towards sustainable development? Evidence from Italy

\section{(Lim et al., Journal of Cleaner}

2017)

(Kamari et al., 2017)

(Schröpfer et al. 2017)

Engineering, Construction and

Architectural

Management
International Journal of Sustainable Built Environment
(Cavicchi and

Vagnoni, 2017)
Focusing on sustainable supply chain management, they developed a hierarchical structural model that showed the importance of $\mathrm{KM}$ and environment for supply chain operations improvements.

Kamari et al. (2017) developed a sustainability framework to support the development and analysis of building renovations aspects. Additionally, the framework may be also used to base decisionmaking regarding for the whole lifecycle of the project.

Schröpfer et al. (2017) through KM, analyzed the transference of knowledge in construction projects that provide sustainable office buildings. In their study, they map the "knowledge flows in project teams that are delivering office buildings to sustainability standards" (p. 242). The results show that much tacit knowledge have been transferred between project teams, resulting in improved knowledge transfer especially among all project participants, which guarantees a specification of ecological building quality.

This transfer is made possible by the establishment of strong ties within the network.

Analyzing healthcare organizations (HCOs), the authors verify how intellectual capital may be used to address sustainability issues. The authors verified that managers who
Journal of Cleaner Production considered of high relevance information and communication technologies as well as for advanced technologies used for sustainability targets, also were also the managers that used formal strategies for sustainability.

The authors performed 30 case studies - in Ontario, Canada - to analyze environment impact assessments and establish activities of $\mathrm{KM}$ processes. Among the activities found in
(Bucci and El- Impact Assessment Diraby, 2018) and Project Appraisal
Literature review

Single case study

Interpretive structural model

Soft Systems

Methodology

Survey, single case study and

descriptive statistics
Survey and Stochastic ordering test

Case study 
urban impact assessment: the case of Ontario

A literature-based review on potentials and constraints in the implementation of the sustainable development goals

\section{(Gusmão Caiado Journal of Cleaner et al., 2018) Production}

The influence of entrepreneurial, market, knowledge management orientations on cleaner production and the sustainable competitive advantage

\section{(de Guimarães et Journal of Cleaner al., 2018) Production}

How should firms reconcile their open innovation 29 capabilities for incorporating external actors in innovations aimed at sustainable development?

Developing Sustainable Healthcare Systems in Developing Countries: Examining the Role of Barriers, Enablers and Drivers on Knowledge Management Adoption

eLearning within the 31 Community of Practice for sustainable development

32 Enabling sustainable energy futures: factors influencing 2018) Production

(Karamat et al., 2019a)

Sustainability

\section{(Katernyak et} al., 2018)

(Irani et al., 2017)

Higher Education, Skills and WorkBased Learning
(Behnam et al., Journal of Cleaner the study as important to enable a proper KM for sustainability evaluation, there are: the organizational support for knowledge

enhancement about this issue; the knowledge diffusion for community regarding practices important for a sustainable development, which emphasize the fact that citizens are stakeholders that must be considered and heard in KM; none of these efforts would be effective without an appropriate coordination of the knowledge analysis; at least, to address complex regulations. The authors emphasize

the importance of learning organizations, which insert learning as an intrinsic ability of companies.

Gusmão Caiado et al. (2018) perform a

literature review regarding Sustainable

Development Goals (SDGs), focusing on the interface between sustainability and KM.

They developed a framework to present the path to achieve the SDGs through KM. The framework is composed by a cycle of four steps: education and information, to gather the required knowledge; innovation, to convert the information into products and services, according to the necessity; implement, to put the products and services in the market; and monitor, evaluate the implementation and analyze the need for changes.

De Guimarães et al. (2018) used KM to understand the impacted of strategic drivers

(Entrepreneurial Orientation, Market

Orientation and Guidance in KM) in the performance of sustainability indicators. The results showed Cleaner Production is strongly influenced by strategic drivers. Indeed, when used in combination, these drivers potentiate the chances of success in Cleaner Production. However, when analyzed separately, KM is the driver with that most influence Cleaner Production.

Behnam et al. (2018) conduct eight case studies to analyze the capabilities to innovate with a sustainability focus, in a context of open innovation. The study emphasizes the role of KM for open innovation and conclude that sustainability can be easily inserted in punctual innovations of products and services using the conventional systems, however, a greater attention is required when a broader system of innovation is under analysis.

The study analyzes the difficulties and facilitators of knowledge management use for inserting sustainable development in Pakistan's healthcare sector. Among their findings, it is highlighted the importance of government support to encourage KM within this sector.

Literature review

Survey and PLSSEM

Case Studies

Delphi method (FDM) and Partia Least Squares Structural Equation Modelling (PLSSEM)

The research used knowledge management in order to encourage a proper management for local development projects.

The authors aimed to analyze how KM may be used to support green supply chain collaboration. They identified 24 factors 
green supply chain collaboration

An Ontology-Based Domain

A practice mining system for 34 the delivery of sustainable retirement villages

Dynamic Knowledge Support

35 Model for Decision-Making and Sustainable Growth: An Empirical Study

Integrating knowledge

36 management in sustainability risk management practices for company survival

Knowledge Graph in Smar Education: A Case Study of

37 Entrepreneurship Scientific Publication Management

Managing Knowledge to Promote Sustainability in Australian Transport Infrastructure Projects

Promoting Healthcare Sustainability in Developing

Countries: Analysis of

Knowledge Management

Drivers in Public and Private Hospitals of Pakistan

Rationalizing a Personalized

Conceptualization for the

Digital Transition and

40 Sustainability of Knowledge

Management Using the

SVIDT Method

Risk Management and

41 Knowledge Management as

Critical Success Factors of

Sustainability Projects

Sustainable Knowledge Management and Its Impact on the Performances of

Biotechnology Organizations
(Konys, 2018)

Sustainability

(Hu et al., 2018)

Journal of Cleaner

Production

(Sandhawalia and Dalcher 2015)

(Manab and

Aziz, 2019)

Management Science Letters

roup Decision and Negotiation

(Chi et al., 2018) Sustainability

(Yang et al., 2015)

Sustainability

of Environmental

Research and Public Health

(Schmitt, 2018)

Sustainability

(Doskočil and

Lacko, 2018)

Sustainability

(Zbuchea et al. 2019) through which KM may materialize this support.

The author developed an ontology to evaluate sustainability through a knowledge

management proposal. The created ontology may support other researchers sustainability assessment approaches to be used.

The authors created a case-based reasoning practice mining system (CBR-PMS) to be used as a knowledge management tool to improve the use of sustainable practices by retirement villages.

The authors developed a model to use KM to support decision making and sustainability analysis for companies. Their model "allows organisations to develop sustainable development and growth and improve social and environmental impact in the long term"

The research investigated the role of KM to benefit the relationship between organizational resilience - via sustainability risk management - and organizations' success. The authors proved the positive relation of the analyzed constructs.

The research presents a scientific knowledge management model to support sustainabilityrelated learning. Through the created model, the students are enabled to think critically and holistically.

The paper aimed to understand the key aspects of KM to support sustainability in Australian Transport Infrastructure Projects. A conceptual framework for KM was created. Among the conclusions from the study, the authors highlighted the importance of run these projects without jeopardizing aspects of sustainability, which is a conscious challenge.

Focusing on sustainability in healthcare, the research investigated what leads Pakistan hospitals to adopt KM. Nineteen drivers were found. From them, the most important was to obtain competitive advantage.

The article aims to present how SVIDT methodology (Strengths, Vulnerability, and Intervention Assessment related to Digital

Threats) can be used to assist Personal

Knowledge Management (PKM) System.

Through the investigation of Critical Success Factors, the research aimed to analyze how risk management and knowledge management are used for sustainability projects. The results showed the importance of KM for the success of these projects, especially after the implementation of them.

The research aimed to analyze the impact of $\mathrm{KM}$ in Romanian biotechnology organizations performance. The study showed that the analyzed sector requires improvements in $\mathrm{KM}$ (p. 818) Econometric model to test hypothesis

Case studies for system development

Case study

Survey and Partia Least Squares Structural Equation Modelling (PLSSEM)

Case study

Survey and simple statistics

Fuzzy Delphi

Method and

Interpretive Structural Modeling

SVIDT

methodology.

Case study strategies. 


\begin{tabular}{|c|c|c|c|c|c|}
\hline 43 & $\begin{array}{l}\text { The impact of corporate } \\
\text { social responsibility (CSR) } \\
\text { knowledge on corporate } \\
\text { financial performance: } \\
\text { evidence from the European } \\
\text { banking industry }\end{array}$ & $\begin{array}{l}\text { (Gangi et al., } \\
\text { 2019) }\end{array}$ & $\begin{array}{l}\text { Journal of } \\
\text { Knowledge } \\
\text { Management }\end{array}$ & $\begin{array}{l}\text { The authors investigate the link between KM } \\
\text { and corporate social responsibility (CSR) to } \\
\text { understand its impact on European banking } \\
\text { industry. Their findings showed that bank } \\
\text { may benefit from this link. }\end{array}$ & $\begin{array}{l}\text { Regression analysis } \\
\text { and the two-stage } \\
\text { Heckman model }\end{array}$ \\
\hline 44 & $\begin{array}{l}\text { The Role of Agribusiness } \\
\text { Innovation Incubation for } \\
\text { Africa's Development }\end{array}$ & (Ozor, 2013) & $\begin{array}{l}\text { African Journal of } \\
\text { Science, Technology, } \\
\text { Innovation and } \\
\text { Development }\end{array}$ & $\begin{array}{l}\text { The research "examines the economic, social } \\
\text { and knowledge management opportunities } \\
\text { offered through agribusiness innovation } \\
\text { incubation for Africa's sustainable } \\
\text { development" (p. 242). Regarding KM } \\
\text { opportunities, the authors highlight the lack of } \\
\text { use of knowledge from researches institutions } \\
\text { of African countries in agriculture and point } \\
\text { out the opportunity of incubation to transfer } \\
\text { this knowledge. }\end{array}$ & Qualitative analysis \\
\hline 45 & $\begin{array}{l}\text { The Roles of Power Distance } \\
\text { Orientation and Perceived } \\
\text { Insider Status in the } \\
\text { Subordinates' Moqi with } \\
\text { Supervisors and Sustainable } \\
\text { Knowledge-Sharing }\end{array}$ & $\begin{array}{c}\text { (Zheng et al., } \\
\text { 2019) }\end{array}$ & Sustainability & $\begin{array}{l}\text { The research analyzes the influence of "the } \\
\text { relationship between subordinates and } \\
\text { supervisors" (p. 2) on knowledge sharing, in } \\
\text { the context of sustainability. The authors } \\
\text { show that the analyzed relationship is positive } \\
\text { and, therefore, it should be properly build to } \\
\text { increase knowledge-sharing within the } \\
\text { organization. }\end{array}$ & $\begin{array}{l}\text { Confirmatory factor } \\
\text { analysis (CFA) }\end{array}$ \\
\hline
\end{tabular}

Table 2 illustrates the fact that many articles used case studies as a research strategy. It is worth mentioning that of this total, 3 articles used the case study in combination with other research strategies, such as survey and descriptive statistics, as can be observed in the articles of Robinson et al. (2006), Trencher et al. (2014) and Schröpfer et al. (2017). Still following this research strategy, two articles used studies of multiple cases: Robinson et al. (2006) and Behnam et al. (2018). It should be noted that the article of Shiroyama et al. (2012) proposes a conceptual model based on the literature review and validates the same through the use of data from real cases of the government, facts not considered in this classification as a case study. The same is valid for $\mathrm{Hu}$ et al. (2018), in which case studies were used to collect data to assist the development of a CBR-PMS (case-based reasoning - practice mining system).

Analyzing the articles that presented Survey as a research strategy, in addition to the aforementioned articles (combined with a case study), those that present the use of a survey with other research strategies, such as Partial Least Squares - Structural Equation Modeling (PLS-SEM) (Banihashemi et al., 2017; de Guimarães et al., 2018; Manab and Aziz, 2019; Roxas and Chadee, 2016), Document Analyses (Kaiser et al., 2016), Stochastic ordering test (Cavicchi and Vagnoni, 2017), simple statistics (Yang et al., 2015) and General Linear Methods (Mohamed et al., 2009). It is worth mentioning the articles that used PLS-SEM to treat the data obtained through the survey since it is a relevant tool for exploratory research in areas such as KM and sustainability.

Analyzing Table 2, it is possible to identify five articles that adopted the literature review as a central research strategy: Preuss and Córdoba-Pachon (2009), Evangelista and Durst (2015), Sánchez and Mitchell (2017), Gusmão Caiado et al. (2018), Irani et al. (2017). It is noteworthy that 4 articles presented the use of literature review combined with other research strategies, such as applications of the developed structure in real cases (Shiroyama et al., 2012), analysis with stakeholders (Wu and Haasis, 2013), empirical evidence (Pietrosemoli and Rodríguez Monroy, 2013), and ontology construction (Konys, 
2018). It is also important to highlight the articles with a research strategy of smaller occurrences, such as Interpretive Structural Model (Lim et al., 2017) and Soft Systems Methodology (Kamari et al., 2017).

Analyzing the research opportunities, from the research strategies to be adopted, there is a lack of articles that used action research as the main focus. There were no occurrences of the use of this strategy in researches involving KM in the context of sustainability. In general, it is necessary to focus on research with the development of actions that allow the consolidation, diffusion and mainly the structuring, development and application of tools to achieve practical results. Therefore, the use of this kind of strategy may be helpful and should be better explored by the literature. As pointed out by Wittmayer et al. (2014), the use of action research contributes to addressing sustainability issues and its challenges.

The results suggest that it is possible to identify little explored scopes of KM in the context of sustainability. The analysis of the scope shows that only one article dealt with KM and Sustainability in small and medium enterprises (Roxas and Chadee, 2016). These same authors point out the lack of research in this area and emphasize the importance of this type of management given the limitation of existing resources for this kind of company. Moreover, it is worth highlighting that only two articles sought to analyze the role of universities in the context of KM and sustainability (Hope, 2016; Trencher et al., 2014). In this sense, it becomes crucial for further research in the area seeking to emphasize the central role of the University as a source of knowledge for the pursuit of sustainable development. Another unexplored scope that deserves to be highlighted is the inclusion of $\mathrm{KM}$ in the sustainability of productive and logistical operations. Only one article briefly highlighted the importance of this topic (Lopes et al., 2017), where companies through KM seek to minimize their impacts, ensuring that the management of raw materials is linked to ecological, social and environmental aspects. Research focused on this thematic can be an important source of information, providing lessons learned regarding practices of cleaner production in productive and logistical operations, obtained through proper use of KM.

From the point of view of the research objectives, we identified as research opportunities the development of specific models, tools and systems to facilitate the sharing of information, since most of the articles emphasize the importance of knowledge sharing among the stakeholders involved in a system. Another point that deserves to be highlighted is the lack of research that aims to develop tools to measure the level of integration of knowledge management in productive systems to achieve sustainability guidelines, most of the research that uses KM in this context is developed with qualitative approach.

\section{Conclusions}

According to the analysis of recent literature, it was concluded that the proposed objectives were reached and that the systematic review of the literature provided satisfactory answers to the research question that guided this study. Responding to the research question, the literature review allowed the identification of several articles involving $\mathrm{KM}$ in the context of sustainability. The use of $\mathrm{KM}$ was analyzed according to 
the research objectives, results achieved, and research strategies used in each article. Following this strategy, it was possible to obtain an overview of the articles published in this area, highlighting their central information and identifying the research opportunities regarding this thematic.

In this sense, when reviewing the literature, it was possible to identify areas with little exploration involving KM in the context of sustainability. Among them, the analysis and identification of actions for small and medium companies meet the guidelines of sustainable development, the exploration of the potential of the Universities in the sense of generating knowledge for the search of a more sustainable society and studies that aim to analyze and propose guidelines for the adequacy of productive operations aiming at achieving sustainable goals. In addition, from the point of view of research strategies, the lack of studies using action research as a central focus stands out. Looking at the research opportunities from the point of view of the research objectives, the need was identified for the development of specific models, tools and systems to facilitate the sharing of information and, in addition, the development of KM insertion level measurement tools in productive systems to reach sustainability guidelines, since most of the identified models qualitatively analyze the use of KM in this context. In summary, our findings show that there is a gap in the literature on practical aspects of KM in the context of sustainability. Therefore, research with practical focus are required and the path may be the use of action research and the development of methodologies to enable this KM.

If not realized, the potential contribution from such research may slow down the further evolution of the process of knowledge management.

\section{Implications for theory and practice}

This paper has three main implications to theory and practice. Firstly, it provides a solid background to the subject matter of knowledge management in the context of sustainability. Secondly, the literature review offers unique insights into the theme and outlines some of the challenges related to it. Finally, opportunities for future research are described, which may be followed up in further works.

Regarding the limitations of this research, it is possible to emphasize the non-use of some databases due to the non-possibility of access to the articles of such bases. The study focused on identifying how KM is being inserted in the context of sustainability. In order to contribute to the literature of KM in the context of sustainability, suggestions for future research on the subject were presented. More detailed reviews by increasing the number of bases analyzed and including the evaluation of the objectives of each study to support the choice of a particular method or tool in a future application. It was also perceived the opportunity to develop more models and tools that evaluate the KM in sustainable projects, that is, that analyze the application of KM in practical results of sustainability.

A future research agenda for knowledge management in the context of sustainability may include an emphasis on the following matters:

i. a sectoral analysis of how knowledge management may be implemented in the 

different branches of industry
ii. assessments of the potentials for promoting knowledge management
as a systematic tool for information exchange among stakeholders,
iii. capacity building on knowledge management

Finally, the development of tools to foster knowledge management for institutional development may also be the subject of further studies.

\section{References}

Aarseth, W., Ahola, T., Aaltonen, K., Økland, A., Andersen, B., 2017. Project sustainability strategies: A systematic literature review. Int. J. Proj. Manag. 35, 1071-1083. https://doi.org/10.1016/j.ijproman.2016.11.006

Aarseth, W., Rolstadås, A., Andersen, B., 2011. Key factors for management of global projects: a case study. Int. J. Transitions Innov. Syst. 1, 326. https://doi.org/10.1504/IJTIS.2011.044905

Al-Jayyousi, O., 2004. Greywater reuse: knowledge management for sustainability. Desalination 167, 27-37. https://doi.org/10.1016/j.desal.2004.06.110

Al Ahbabi, S.A., Singh, S.K., Balasubramanian, S., Gaur, S.S., 2018. Employee perception of impact of knowledge management processes on public sector performance. J. Knowl. Manag. https://doi.org/10.1108/JKM-08-2017-0348

Al Saifi, S.A., 2015. Positioning organisational culture in knowledge management research. J. Knowl. Manag. 19, 164-189. https://doi.org/10.1108/JKM-07-20140287

Banihashemi, S., Hosseini, M.R., Golizadeh, H., Sankaran, S., 2017. Critical success factors (CSFs) for integration of sustainability into construction project management practices in developing countries. Int. J. Proj. Manag. 35, 1103-1119. https://doi.org/10.1016/j.ijproman.2017.01.014

Baraki, Y.A., Brent, A.C., 2013. Technology transfer of hand pumps in rural communities of Swaziland: Towards sustainable project life cycle management. Technol. Soc. 35, 258-266. https://doi.org/10.1016/j.techsoc.2013.10.001

Behnam, S., Cagliano, R., Grijalvo, M., 2018. How should firms reconcile their open innovation capabilities for incorporating external actors in innovations aimed at sustainable development? J. Clean. Prod. 170, 950-965. https://doi.org/10.1016/j.jclepro.2017.09.168

Bhandari, R., Saptalena, L.G., Kusch, W., 2018. Sustainability assessment of a micro hydropower plant in Nepal. Energy. Sustain. Soc. 8, 3. https://doi.org/10.1186/s13705-018-0147-2

Biswas, I., Raj, A., Srivastava, S.K., 2018. Supply chain channel coordination with triple bottom line approach. Transp. Res. Part E Logist. Transp. Rev. 115, 213-226. https://doi.org/10.1016/j.tre.2018.05.007

Bolisani, E., Bratianu, C., 2017. Knowledge strategy planning: an integrated approach to 
manage uncertainty, turbulence, and dynamics. J. Knowl. Manag. 21, 233-253. https://doi.org/10.1108/JKM-02-2016-0071

Brundtland, G., 1987. Our common future, World Commission on Environment and Development. Oxford University Press, Oslo.

Bucci, M., El-Diraby, T.E., 2018. The functions of knowledge management processes in urban impact assessment: the case of Ontario. Impact Assess. Proj. Apprais. 36, 265280. https://doi.org/10.1080/14615517.2018.1445179

Burki, U., Ersoy, P., Dahlstrom, R., 2018. Achieving triple bottom line performance in manufacturer-customer supply chains: Evidence from an emerging economy. J. Clean. Prod. 197, 1307-1316. https://doi.org/10.1016/j.jclepro.2018.06.236

Cavicchi, C., Vagnoni, E., 2017. Does intellectual capital promote the shift of healthcare organizations towards sustainable development? Evidence from Italy. J. Clean. Prod. 153, 275-286. https://doi.org/10.1016/j.jclepro.2017.03.175

Chang, D.L., Sabatini-Marques, J., da Costa, E.M., Selig, P.M., Yigitcanlar, T., 2018. Knowledge-based, smart and sustainable cities: a provocation for a conceptual framework. J. Open Innov. Technol. Mark. Complex. 4, 5. https://doi.org/10.1186/s40852-018-0087-2

Chi, Y., Qin, Y., Song, R., Xu, H., 2018. Knowledge Graph in Smart Education: A Case Study of Entrepreneurship Scientific Publication Management. Sustainability 10, 995. https://doi.org/10.3390/su10040995

Ciumasu, I.M., 2013. Dynamic decision trees for building resilience into future eco-cities. Technol. Forecast. Soc. Change 80, 1804-1814. https://doi.org/10.1016/j.techfore.2012.12.010

de Guimarães, J.C.F., Severo, E.A., de Vasconcelos, C.R.M., 2018. The influence of entrepreneurial, market, knowledge management orientations on cleaner production and the sustainable competitive advantage. J. Clean. Prod. 174, 1653-1663. https://doi.org/10.1016/j.jclepro.2017.11.074

Denyer, D., Tranfield, D., 2009. Producing a systematic review, in: Buchanan, D.A., Bryman, A. (Eds.), The Sage Handbook of Organizational Research Methods. SAGE Publications Ltd, Thousand Oaks, pp. 671-689.

Depken, D., Zeman, C., 2018. Small business challenges and the triple bottom line, TBL: Needs assessment in a Midwest State, U.S.A. Technol. Forecast. Soc. Change 135, 44-50. https://doi.org/10.1016/j.techfore.2017.05.032

Djeflat, A., 2010. Sustainable knowledge for sustainable development: challenges and opportunities for African development. World J. Sci. Technol. Sustain. Dev. 7, 131149. https://doi.org/10.1108/20425945201000009

Doskočil, R., Lacko, B., 2018. Risk Management and Knowledge Management as Critical Success Factors of Sustainability Projects. Sustainability 10, 1438. https://doi.org/10.3390/su10051438

Evangelista, P., Durst, S., 2015. Knowledge management in environmental sustainability practices of third-party logistics service providers. VINE 45, 509-529. https://doi.org/10.1108/VINE-02-2015-0012 
Faber, N., Engelen, J., 2005. The sustainability of "sustainability" — a study into the conceptual foundations of the notion of "sustainability." J. Environ. Assess. Policy Manag. 7, 1-33.

Gangi, F., Mustilli, M., Varrone, N., 2019. The impact of corporate social responsibility (CSR) knowledge on corporate financial performance: evidence from the European banking industry. J. Knowl. Manag. 23, 110-134. https://doi.org/10.1108/JKM-042018-0267

Gaviria-Marin, M., Merigó, J.M., Baier-Fuentes, H., 2019. Knowledge management: A global examination based on bibliometric analysis. Technol. Forecast. Soc. Change 140, 194-220. https://doi.org/10.1016/j.techfore.2018.07.006

Gonzaga de Albuquerque, A.P., Coutinho de Melo, F.J., Dumke de Medeiros, D., Tomaz de Aquino, J., De Barros Jerônimo, T., 2018. Knowledge management alignment to the community of practice in a company of cutting and bending steel. Brazilian J. Oper. Prod. Manag. 15, 1-11. https://doi.org/10.14488/bjopm.2018.v15.n1.a1

Gusmão Caiado, R.G., Leal Filho, W., Quelhas, O.L.G., Luiz de Mattos Nascimento, D., Ávila, L.V., 2018. A literature-based review on potentials and constraints in the implementation of the sustainable development goals. J. Clean. Prod. 198, 12761288. https://doi.org/10.1016/j.jclepro.2018.07.102

Halati, A., He, Y., 2018. Intersection of economic and environmental goals of sustainable development initiatives. J. Clean. Prod. https://doi.org/10.1016/j.jclepro.2018.03.322

Hamdoun, M., Chiappetta Jabbour, C.J., Ben Othman, H., 2018. Knowledge transfer and organizational innovation: Impacts of quality and environmental management. J. Clean. Prod. 193, 759-770. https://doi.org/10.1016/j.jclepro.2018.05.031

Holsapple, C.W., Joshi, K.D., 2000. An investigation of factors that influence the management of knowledge in organizations. J. Strateg. Inf. Syst. 9, 235-261. https://doi.org/10.1016/S0963-8687(00)00046-9

Hope, A., 2016. Creating sustainable cities through knowledge exchange. Int. J. Sustain. High. Educ. 17, 796-811. https://doi.org/10.1108/IJSHE-04-2015-0079

Hu, X., Xia, B., Chen, Q., Skitmore, M., Buys, L., Wu, P., 2018. A practice mining system for the delivery of sustainable retirement villages. J. Clean. Prod. 203, 943-956. https://doi.org/10.1016/j.jclepro.2018.08.184

Huang, C., Huang, T., Chen, W., 2009. Int . J . Production Economics Communication protocols for order management in collaborative manufacturing. Intern. J. Prod. Econ. 122, 257-268. https://doi.org/10.1016/j.ijpe.2009.06.004

Hussinki, H., Kianto, A., Vanhala, M., Ritala, P., 2017. Assessing the universality of knowledge management practices. J. Knowl. Manag. 21, 1596-1621. https://doi.org/10.1108/JKM-09-2016-0394

Intezari, A., Taskin, N., Pauleen, D.J., 2017. Looking beyond knowledge sharing: an integrative approach to knowledge management culture. J. Knowl. Manag. 21, 492515. https://doi.org/10.1108/JKM-06-2016-0216

Irani, Z., Kamal, M.M., Sharif, A., Love, P.E.D., 2017. Enabling sustainable energy futures: factors influencing green supply chain collaboration. Prod. Plan. Control 28, 
684-705. https://doi.org/10.1080/09537287.2017.1309710

Javernick-Will, A.N., Scott, W.R., 2010. Who Needs to Know What? Institutional Knowledge and Global Projects. J. Constr. Eng. Manag. 136, 546-557. https://doi.org/10.1061/(ASCE)CO.1943-7862.0000035

Kaiser, D.B., Köhler, T., Weith, T., 2016. Knowledge management in sustainability research projects: Concepts, effective models, and examples in a multi-stakeholder environment. Appl. Environ. Educ. Commun. 15, 4-17. https://doi.org/10.1080/1533015X.2016.1141720

Kamari, A., Corrao, R., Kirkegaard, P.H., 2017. Sustainability focused decision-making in building renovation. Int. J. Sustain. Built Environ. 6, 330-350. https://doi.org/10.1016/j.ijsbe.2017.05.001

Karamat, J., Shurong, T., Ahmad, N., Afridi, S., Khan, S., Khan, N., 2019a. Developing Sustainable Healthcare Systems in Developing Countries: Examining the Role of Barriers, Enablers and Drivers on Knowledge Management Adoption. Sustain. 11. https://doi.org/10.3390/su11040954

Karamat, J., Shurong, T., Ahmad, N., Afridi, S., Khan, S., Mahmood, K., 2019b. Promoting Healthcare Sustainability in Developing Countries: Analysis of Knowledge Management Drivers in Public and Private Hospitals of Pakistan. Int. J. Environ. Res. Public Health 16, 508. https://doi.org/10.3390/ijerph16030508

Katernyak, I., Loboda, V., Kulya, M., 2018. eLearning within the Community of Practice for sustainable development. High. Educ. Ski. Work. Learn. 8, 312-322. https://doi.org/10.1108/HESWBL-03-2018-0030

Kaur, A., Sharma, P.C., 2018. Social sustainability in supply chain decisions: Indian manufacturers. Environ. Dev. Sustain. 20, 1707-1721. https://doi.org/10.1007/s10668-017-9961-5

Kivilä, J., Martinsuo, M., Vuorinen, L., 2017. Sustainable project management through project control in infrastructure projects. Int. J. Proj. Manag. 35, 1167-1183. https://doi.org/10.1016/j.ijproman.2017.02.009

Konys, A., 2018. An Ontology-Based Knowledge Modelling for a Sustainability Assessment Domain. Sustainability 10, 300. https://doi.org/10.3390/su10020300

Kudratova, S., Huang, X., Zhou, X., 2018. Sustainable project selection : Optimal project selection considering sustainability under reinvestment strategy. J. Clean. Prod. 203, 469-481. https://doi.org/10.1016/j.jclepro.2018.08.259

Lim, M.K., Tseng, M.-L., Tan, K.H., Bui, T.D., 2017. Knowledge management in sustainable supply chain management: Improving performance through an interpretive structural modelling approach. J. Clean. Prod. 162, 806-816. https://doi.org/10.1016/j.jclepro.2017.06.056

Liu, Y., Chan, C., Zhao, C., Liu, C., 2018. Unpacking knowledge management practices in China: do institution, national and organizational culture matter? J. Knowl. Manag. https://doi.org/10.1108/JKM-07-2017-0260

Loon, M., 2019. Knowledge management practice system: Theorising from an international meta-standard. J. Bus. Res. 94, 432-441. https://doi.org/10.1016/j.jbusres.2017.11.022 
Lopes, C.M., Scavarda, A., Hofmeister, L.F., Thomé, A.M.T., Vaccaro, G.L.R., 2017. An analysis of the interplay between organizational sustainability, knowledge management, and open innovation. J. Clean. Prod. 142, 476-488. https://doi.org/10.1016/j.jclepro.2016.10.083

Manab, N.A., Aziz, N.A.A., 2019. Integrating knowledge management in sustainability risk management practices for company survival. Manag. Sci. Lett. 9, 585-594. https://doi.org/10.5267/j.msl.2019.1.004

Martinsons, M.G., Davison, R.M., Huang, Q., 2017. International Journal of Information Management Strategic knowledge management failures in small professional service fi rms in China. Int. J. Inf. Manage. 37, 327-338. https://doi.org/10.1016/j.ijinfomgt.2017.04.003

Maruyama, Ú., Quintanilha, M.V.B., Silva, C.M. dos S., Sanchez, P.M., 2019. Sustainability and green marketing challenge: Brazilian brewing industry case study. Brazilian J. Oper. Prod. Manag. 16, 78-87. https://doi.org/10.14488/BJOPM.2019.v16.n1.a7

Mohamed, M., Stankosky, M., Mohamed, M., 2009. An empirical assessment of knowledge management criticality for sustainable development. J. Knowl. Manag. 13, 271-286. https://doi.org/10.1108/13673270910988105

Moraes, S. de S., Chiappetta Jabbour, C.J., Battistelle, R.A.G., Rodrigues, J.M., Renwick, D.S.W., Foropon, C., Roubaud, D., 2018. When knowledge management matters: interplay between green human resources and eco-efficiency in the financial service industry. J. Knowl. Manag. https://doi.org/10.1108/JKM-07-2018-0414

Nisar, T.M., Prabhakar, G., Strakova, L., 2019. Social media information bene fi ts , knowledge management and smart organizations. J. Bus. Res. 94, 264-272. https://doi.org/10.1016/j.jbusres.2018.05.005

Nonaka, I., Toyama, R., Nagata, A., 2000. A Firm as a Knowledge-creating Entity: A New Perspective on the Theory of the Firm. Ind. Corp. Chang. 9, 1-20.

Oliva, F.L., Semensato, B.I., Prioste, D.B., Winandy, E.J.L., Bution, J.L., Couto, M.H.G., Bottacin, M.A., Mac Lennan, M.L.F., Teberga, P.M.F., Santos, R.F., Singh, S.K., da Silva, S.F., Massaini, S.A., 2019. Innovation in the main Brazilian business sectors: characteristics, types and comparison of innovation. J. Knowl. Manag. 23, 135-175. https://doi.org/10.1108/JKM-03-2018-0159

Ozor, N., 2013. The role of agribusiness innovation incubation for Africa's development. African J. Sci. Technol. Innov. Dev. 5, 242-249. https://doi.org/10.1080/20421338.2013.796742

Peng, J., Li-Hua, R., Moffett, S., 2007. Trend of knowledge management in China: challenges and opportunities. J. Technol. Manag. China 2, 198-211. https://doi.org/10.1108/17468770710825142

Pietrosemoli, L., Rodríguez Monroy, C., 2013. The impact of sustainable construction and knowledge management on sustainability goals. A review of the Venezuelan renewable energy sector. Renew. Sustain. Energy Rev. 27, 683-691. https://doi.org/10.1016/j.rser.2013.07.056

Pogutz, S., Winn, M.I., 2016. Cultivating Ecological Knowledge for Corporate 
Sustainability: Barilla's Innovative Approach to Sustainable Farming. Bus. Strateg. Environ. 25, 435-448. https://doi.org/10.1002/bse.1916

Preuss, L., Córdoba-Pachon, J., 2009. A knowledge management perspective of corporate social responsibility. Corp. Gov. Int. J. Bus. Soc. 9, 517-527. https://doi.org/10.1108/14720700910985052

Prusak, R., 2014. Influence of selected strategic variables on the development of the intellectual capital of an enterprise. Management 18, 199-212. https://doi.org/10.2478/manment-2014-0015

Puente-Rodríguez, D., van Slobbe, E., Al, I.A.C., Lindenbergh, D.E. (Danny), 2016. Knowledge co-production in practice: Enabling environmental management systems for ports through participatory research in the Dutch Wadden Sea. Environ. Sci. Policy 55, 456-466. https://doi.org/10.1016/j.envsci.2015.02.014

Quast, L., 2012. Why knowledge management is important to the success of your company. Forbes.

Rabeea, O., Nassar, I.A., Khalid, M., 2019. Knowledge management processes and sustainable competitive advantage : An empirical examination in private universities 94, 320-334. https://doi.org/10.1016/j.jbusres.2018.02.013

Reijsen, J. van, Helms, R., Batenburg, R., Foorthuis, R., 2015. The impact of knowledge management and social capital on dynamic capability in organizations. Knowl. Manag. Res. Pract. 401-417. https://doi.org/10.1057/kmrp.2013.59

Robinson, H.S., Anumba, C.J., Carrillo, P.M., Al-Ghassani, A.M., 2006. STEPS: a knowledge management maturity roadmap for corporate sustainability. Bus. Process Manag. J. 12, 793-808. https://doi.org/10.1108/14637150610710936

Rosati, F., Faria, L.G.D., 2019. Addressing the SDGs in sustainability reports: The relationship with institutional factors. J. Clean. Prod. 215, 1312-1326. https://doi.org/10.1016/j.jclepro.2018.12.107

Roscoe, S., Subramanian, N., Jabbour, C.J.C., Chong, T., 2019. Green human resource management and the enablers of green organisational culture: Enhancing a firm's environmental performance for sustainable development. Bus. Strateg. Environ. 113. https://doi.org/10.1002/bse.2277

Roxas, B., Chadee, D., 2016. Knowledge management view of environmental sustainability in manufacturing SMEs in the Philippines. Knowl. Manag. Res. Pract. 14, 514-524. https://doi.org/10.1057/kmrp.2015.30

Sánchez, L.E., Mitchell, R., 2017. Conceptualizing impact assessment as a learning process. Environ. Impact Assess. Rev. 62, 195-204. https://doi.org/10.1016/j.eiar.2016.06.001

Sandhawalia, B.S., Dalcher, D., 2015. Dynamic knowledge support model for decisionmaking and sustainable growth: An empirical study. Gr. Decis. Negot. 24, 803-823. https://doi.org/10.1007/s10726-014-9413-7

Santoro, G., Vrontis, D., Thrassou, A., Dezi, L., 2018. Technological Forecasting \& Social Change The Internet of Things : Building a knowledge management system for open innovation and knowledge management capacity. Technol. Forecast. Soc. Chang. 136, 347-354. https://doi.org/10.1016/j.techfore.2017.02.034 
Schmitt, U., 2018. Rationalizing a Personalized Conceptualization for the Digital Transition and Sustainability of Knowledge Management Using the SVIDT Method. Sustainability 10, 839. https://doi.org/10.3390/su10030839

Schröpfer, V.L.M., Tah, J., Kurul, E., 2017. Mapping the knowledge flow in sustainable construction project teams using social network analysis. Eng. Constr. Archit. Manag. 24, 229-259. https://doi.org/10.1108/ECAM-08-2015-0124

Sekino, T., Nakamura, M., 2006. Application of knowledge management to environmental management projects: A case study for lake management. Lakes Reserv. Res. Manag. 11, 97-102. https://doi.org/10.1111/j.1440-1770.2006.00295.x

Severo, E.A., de Guimarães, J.C.F., Henri Dorion, E.C., 2018. Cleaner production, social responsibility and eco-innovation: Generations' perception for a sustainable future. J. Clean. Prod. 186, 91-103. https://doi.org/10.1016/j.jclepro.2018.03.129

Shiroyama, H., Yarime, M., Matsuo, M., Schroeder, H., Scholz, R., Ulrich, A.E., 2012. Governance for sustainability: knowledge integration and multi-actor dimensions in risk management. Sustain. Sci. 7, 45-55. https://doi.org/10.1007/s11625-011-0155Z

Singh, S.K., 2019. Territoriality, task performance, and workplace deviance: Empirical evidence on role of knowledge hiding. J. Bus. Res. 97, 10-19. https://doi.org/10.1016/j.jbusres.2018.12.034

Singh, S.K., El-Kassar, A.-N., 2019. Role of big data analytics in developing sustainable capabilities. J. Clean. Prod. 213, 1264-1273. https://doi.org/10.1016/j.jclepro.2018.12.199

Singh, S.K., Singh, A.P., 2018. Interplay of organizational justice, psychological empowerment, organizational citizenship behavior, and job satisfaction in the context of circular economy. Manag. Decis. https://doi.org/10.1108/MD-09-20180966

Spangler, W., Sroufe, R., Madia, M., Singadivakkam, J., 2014. Sustainability-Focused Knowledge Management in a Global Enterprise. J. Comput. Inf. Syst. 55, 70-82. https://doi.org/10.1080/08874417.2014.11645742

Trencher, G., Bai, X., Evans, J., McCormick, K., Yarime, M., 2014. University partnerships for co-designing and co-producing urban sustainability. Glob. Environ. Chang. 28, 153-165. https://doi.org/10.1016/j.gloenvcha.2014.06.009

Wittmayer, J.M., Schäpke, N., van Steenbergen, F., Omann, I., 2014. Making sense of sustainability transitions locally: how action research contributes to addressing societal challenges. Crit. Policy Stud. 8, 465-485. https://doi.org/10.1080/19460171.2014.957336

$\mathrm{Wu}$, J., Haasis, H.-D., 2013. Converting knowledge into sustainability performance of freight villages. Logist. Res. 6, 63-88. https://doi.org/10.1007/s12159-013-0098-0

Wu, J., Wang, Y., 2006. Measuring KMS success : A respecification of the DeLone and McLean's model 43, 728-739. https://doi.org/10.1016/j.im.2006.05.002

Xavier, A.F., Naveiro, R.M., Aoussat, A., Reyes, T., 2017. Systematic literature review of eco-innovation models: Opportunities and recommendations for future research. J. Clean. Prod. 149, 1278-1302. https://doi.org/10.1016/j.jclepro.2017.02.145 
Yang, J., Yuan, M., Yigitcanlar, T., Newman, P., Schultmann, F., 2015. Managing knowledge to promote sustainability in Australian transport infrastructure projects. Sustain. 7, 8132-8150. https://doi.org/10.3390/su7078132

Yigitcanlar, T., 2011. Position paper : redefining knowledge-based urban development. Int. J. Knowledge-Based Dev. 2, 340-356.

Zbuchea, A., Pînzaru, F., Busu, M., Stan, S.-O., Bârgăoanu, A., 2019. Sustainable Knowledge Management and Its Impact on the Performances of Biotechnology Organizations. Sustainability 11, 359. https://doi.org/10.3390/su11020359

Zhang, W., Padmanabhan, P., Huang, C.H., 2018. Firm level offshoring activities, pollution regulation, triple bottom line, and market structure: What do they have in common? J. Clean. Prod. 195, 618-624. https://doi.org/10.1016/j.jclepro.2018.05.232

Zheng, X., Li, L., Zhang, F., Zhu, M., 2019. The Roles of Power Distance Orientation and Perceived Insider Status in the Subordinates' Moqi with Supervisors and $\begin{array}{llll}\text { Sustainable Knowledge-Sharing. } & \text { Sustainability } & 11, & \end{array}$ https://doi.org/10.3390/su11051421 